М. : Лабиринт, 1999. - 352 с. 4. Гальперин И. Р. Текст как объект лингвистического исследования / И. Р. Гальперин. - М. - 1981. - 139 с. 5. Гаспаров Б. М. Язык. Память. Образ. Лингвистика языкового существования / $\quad$ Б. М. Гаспаров. - М. : Новое литературное обозрение, 1996. - 352 с. 6. Голод Н. С. Українська мова як іноземна: [робочий зошит для студентів II курсу факультету підготовки іноземних громадян (модуль №6, спеціальність «Лікувальна справа», «Стоматологія»)] / Н. С. Голод, М. В. Панчишин, З. Я. Родчин. - Івано-Франківськ : ІФНМУ, 2014. - 202 с. : іл. 7. Золотова Г. А. Роль грамматики в композиции текста // Язык. Культура. Гуманитарное знание / Научное наследие Г. О. Винокура и современность [отв. ред. С. И. Гиндин, Н. Н. Розанова]. - М. : Научный мир, 1999. - 488 с. 8. Куйловська Н. Л. Українська мова як іноземна : [робочий зошит для студентів факультету підготовки іноземних громадян (курс, модуль № 1, модуль № 2; спеціальність «Лікувальна справа», «Стоматологія»)] / Н. Л. Куйловська, У. В. Соловій. - Івано-Франківськ : ІФНМУ, 2013. - 154 с. : іл. 9. Чистякова А. Б. Українська мова для іноземців : [підручник для іноземних студентів вищих навчальних закладів] / А. Б. Чистякова, Л. І. Селівестрова, Т. М. Лагута. - Харків : Індустрія, 2008. - 384 с.

УДК $37.01: 355.233(477)$

Олексій Тогочинський

\title{
ОСНОВНІ ЕТАПИ ТЕХНОЛОГІЇ ФОРМУВАННЯ СОЦІАЛЬНОЇ КОМПЕТЕНТНОСТІ СЛУХАЧІВ ТА КУРСАНТІВ ВИЩИХ НАВЧАЛЬНИХ ЗАКЛАДІВ МВС УКРАЇНИ
}

Тогочинський О. М. Основні етапи технології формування соціальної компетентності слухачів та курсантів вищих навчальних закладів МВС України.

У статті представлено складники технології формування соціальної компетентності як впорядкованої сукупності психолого-педагогічних методів, прийомів, засобів, техніки виконання, спільної діяльності учасників педагогічного процесу, охарактеризовано іiі основні етапи, що пов'язані 3 циклами гуманітарної, соціально-економічної, фундаментальної та практичної підготовки слухачів і курсантів вищих навчальних закладів МВС України.

Ключові слова: соціальна компетентність, технологія, педагогічні умови, курсанти, слухачі, професійна діяльність.

Тогочинский А. М. Основные этапы технологии формирования социальной компетентности слушателей и курсантов высших учебных заведений МВД Украины.

В статье представлены составные технологии формирования социальной компетентности как системы психолого-педагогических методов, приемов, средств, техники выполнения, общей деятельности участников педагогического процесса, охарактеризованы ее основные этапы, связанные с циклами гуманитарной, социальноэкономической, фундаментальной и практической подготовки слушателей и курсантов высших учебных заведений МВД Украины.

Ключевые слова: социальная компетентность, технология, педагогические условия, курсанты, слушатели, профессиональная деятельность.

Tohochynskyy O. M. The main stages of technologies of social competence of students and cadets of higher educational establishments of MIA of Ukraine formation.

The paper deals with the technology components of social competence formation as an arranged set of psychological and pedagogical methods, tools, technique, common activity 
of participants of communication, describes its main stages connected with the cycles of humanitarian, socio-economic, fundamental and practical training students and cadets of higher educational establishments of MIA of Ukraine formation.

Keywords: social competence, technology, pedagogical conditions, cadets, trainees, professional activity.

Нині значення формування у майбутніх правоохоронців соціальної компетентності зумовлена необхідністю реформування правоохоронної системи та входження України до європейського освітнього простору. У документах, що регламентують професійну підготовку майбутніх фахівців (освітньо-кваліфікаційних характеристиках на випускників, наказах та директивах МBC), а також в Указах Президента, нормативно-правових актах Кабінету Міністрів і Верховної Ради України зазначається, що сучасному етапі правоохоронці під час виконання завдань професійної діяльності повинні уміти враховувати особливості соціокультурної ситуації, специфіку переходу українського суспільства від жорстко детермінованого до ринкового, в якому відбувається зміна і переосмислення соціальних цінностей i норм. Це висуває нові вимоги до особистісно-професійних якостей українських правоохоронців, обумовлює необхідність формування та розвитку у них знань, умінь, навичок і якостей, які є складниками соціальної компетентності.

На сьогодні поняття «педагогічна технологія» трактують досить неоднозначно. Зокрема учений В. Сластьонін розглядає педагогічну технологію як впорядковану сукупність дій, операцій і процедур, що інструментально забезпечують досягнення прогнозованого й діагностованого результату в умовах освітнього процесу [7, с. 495]. У свою чергу С. Смирнов цим поняттям позначає сукупність і послідовність використання методів засобів, інструментарію, апаратури, навчального устаткування й технічних засобів для навчального процесу [8]. На думку В. Беспалька, педагогічну технологію слід розглядати як процес комунікації або спосіб виконання навчального завдання, що містить застосування системного аналізу для поліпшення навчання [1 ]. В. Беспалько вважає, що педагогічна технологія $\epsilon$ проектом певної педагогічної системи, іiї практичним вираженням. У свою чергу М. Кларін трактує іï як системну сукупність i порядок функціонування всіх особистісних, інструментальних i методологічних засобів, що використовуються для досягнення педагогічних цілей [4]. П. Підкасистий розглядає педагогічну технологію як певну сферу знання, завданням якої є конструювання оптимальних навчальних систем на основі даних соціальних, управлінських i природничих наук, як сукупність професійних умінь, що забезпечують доброчинний виховний вплив педагога на дитину в контексті взаємодії 3 ним та дозволяє дитині вступати у взаємодію зі світом на рівні культури [5]. На думку В. Гузєєва, педагогічна технологія - це система, що містить уявлення про вихідні дані і плановані результати навчання, засоби діагностування поточного стану суб'єктів навчання, набір моделей навчання і критерії вибору оптимальної моделі навчання для конкретних умов [2].

Окремо слід указати на різні аспекти використання цього поняття. Науковець Г. Селевко наголошує на багатоаспектності педагогічної технології, звертаючи увагу на такі їі ознаки, як рівень застосування, філософська основа, чинники психічного розвитку, орієнтація на особистісні структури, характер змісту й структури, організаційні форми, тип управління пізнавальною діяльністю та ін. [6]. Згідно із класифікацією Г. Селевка, педагогічна технологія функціонує як наука (сфера педагогічної теорії), що досліджує і проектує найбільш раціональні шляхи навчання; як система алгоритмів, способів і результатів діяльності та як реальний процес 
навчання й виховання.

Отже, автори розглядають педагогічну технологію як метод або сукупність прийомів, дидактичну конструкцію інформаційного управління навчальнопізнавальною діяльністю суб'єктів навчання, як модель спільної педагогічної діяльності з проектування й організації навчального процесу.

Метою статmі $є$ характеристика основних етапів технології формування соціальної компетентності слухачів і курсантів вищих навчальних закладів МВС України.

Ми трактуємо технологію формування соціальної компетентності в контексті не освітньої технології, а технології навчання. Нас цікавить технологія як процес досягнення певних результатів щодо зміни стану сформованості соціальної компетентності у курсантів та слухачів 3 використанням відповідної сукупності методів, засобів і способів діяльності. При цьому нам імпонує думка І. Дичківської про те, що технологія навчання - це тип технології, яка моделює шлях освоєння конкретного навчального матеріалу в межах відповідного навчального предмета, теми, питання. За багатьма параметрами вона $є$ наближеною до окремої методики та охоплює зміст, методи та форми навчання [3, с. 68].

Відповідно до досліджень вчених (В. Беспалько [1], В. Гузєєв [2], І. Дичківська [3], М. Кларін [4], Г. Селевко [6]) технологію ми трактуємо як алгоритм організації діяльності курсантів з урахуванням соціально-психологічних, соціально-педагогічних та соціокультурних чинників у навчальному закладі. Це впорядкована сукупність психолого-педагогічних методів, прийомів, засобів, змістовна техніка виконання, спільна діяльність учасників педагогічного процесу задля досягнення конкретною педагогічного результату - формування соціальної компетентності фахівців ОВС. Педагогічна технологія формування соціальної компетентності визначає систему професійної діяльності викладача для створення психолого-педагогічних умов і надання можливостей для успішної соціалізації курсантів та слухачів у ситуації навчальної взаємодії й подальшої професійної діяльності.

Для розроблення технології формування соціальної компетентності курсантів і слухачів ОВС ми передбачаємо насамперед поєднати в одну систему цілі, завдання, методи навчання, способи засвоєння змісту, форм навчально-пізнавальної діяльності, способів контролю, самодіагностування й корекції засвоєння необхідного навчального матеріалу з питань соціальної компетентності.

Технологія формування соціальної компетентності курсантів і слухачів у ВНЗ МВС, нашу думку, повинні передбачати цілеспрямований вплив на основні складові освітнього процесу: навчання (засвоєння в навчальному процесі таких складових соціальної компетентності, як знання, уміння, навички), виховання (орієнтація на соціально і професійно значущі норми поведінки, професійно важливі якості), розвиток (життєвих цінностей, комунікабельності, толерантності, самооцінки, особистісного потенціалу, правової свідомості, моральних уявлень про умови припинення правопорушень, охорони і забезпечення громадського порядку).

Відповідно до прийнятої думки (І. Дичківська, Г. Селевко, В. Сластьонін та ін.), структура технології формування соціальної компетентності майбутніх офіцерів МВС містить такі компоненти: змістовний та процесуальний $[3$, с. 70]. Змістова частина це концептуальна система знань про інструментарій досягнення цілей, ефективності процесу навчання. До змістової (концептуальної) частини можна зарахувати постановку, максимальне уточнення, формулювання цілей, педагогічні умови та етапи.

Ми вважаємо, що основоположною метою розробки технології формування 
соціальної компетентності $\epsilon$ створення умов та можливостей для активного особистісного розвитку й самореалізації майбутніх фахівців МВС в соціальному аспекті. Йдеться про формування у курсантів та слухачів системи емоційно-ціннісних орієнтацій, соціальних і психологічних знань, умінь та навичок працівників органів внутрішніх справ у правоохоронній сфері. У результаті впровадження технології важливо забезпечити у майбутніх фахівців уміння здійснювати ефективну комунікацію і виконувати соціальні ролі у професійному та криміногенному середовищі, сформувати здатності до професійної і соціальної адаптації та самореалізації, спільної командної діяльності, допомогти набути досвіду відповідального i конструктивного вирішення життєвих проблем та конфліктних ситуацій.

Окрім цього, до змістової частини технології слід віднести також педагогічні умови та етапи формування соціальної компетентності майбутніх фахівців ОВС. Концептуальна модель технології формування соціальної компетентності курсантів у навчально-виховному процесі ВНЗ МВС передбачає три основні етапи у професійній підготовці, які умовно співвідносяться з циклами гуманітарної, соціально-економічної, фундаментальної та практичної підготовки.

Це зумовлено тим, що цикл підготовки охоплює сукупність складників змісту освітньої або професійної підготовки (змістових модулів, блоків змістових модулів), що поєднані за приналежністю їх змісту до відповідного освітнього або професійного напряму. Крім того, такий підхід до визначення етапів формування соціальної компетентності узгоджується 3 принципом систематичності й послідовності, коли важливе значення має послідовне, побудоване на логіці науки і зумовлене завданнями освіти та віковими можливостями курсантів і слухачів розгортання змісту знань, способів діяльності у навчальних програмах, підручниках та посібниках з різних дисциплін, а також планомірний порядок навчання, за якого кожний етап спільної діяльності курсантів і слухачів 3 педагогами грунтується на попередніх етапах. Іншими словами, принцип систематичності у формуванні соціальної компетентності стосується як викладання окремих дисциплін, так і навчання загалом. Елементи соціальної компетентності треба подавати так, щоб вони були внутрішньо пов'язані між собою, щоб уся їх сума утворювала цілісність. Цей принцип вимагає також наступності й послідовного й безперервного переходу від нижчого до вищого ступеня викладання i навчання. При такому переході кожний елемент засвоюваного курсантами і слухачами матеріалу грунтується на раніше набутих знаннях i $\epsilon$ результатом їх логічного розвитку. Наступність у формуванні соціальної компетентності стосується як змісту, так і методів навчання, а також способів навчально-пізнавальної діяльності. На кожному етапі важливе значення має попереднє діагностування соціальної компетентності, а за необхідності - відповідна корекція формувальних впливів на ii структурні компоненти (комунікативного, політико-правового, рольового, рефлексивно-психологічного та професійного).

Зокрема перший етап - початковий - пов'язаний з циклом гуманітарної та соціальноекономічної підготовки. Найважливішими педагогічним умовами формування соціальної компетентності курсантів на початковому етапі $\epsilon$ планування цілей формування соціальної компетентності та 3'ясування основних напрямів педагогічної діяльності, за посередництвом яких можна досягти таких цілей; забезпечення усвідомлення курсантами своїх потенційних здібностей i можливостей щодо соціальної компетентності; урахування індивідуальних, особистісних та професійних характеристик курсантів під час формування у них усіх компонентів соціальної компетентності; формування усвідомленого та зацікавленого ставлення курсантів до набуття знань, умінь і навичок- складників соціальної компетентності в аспекті 
підготовки до майбутньої професійної діяльності; розвиток у майбутніх фахівців мотивації до набуття умінь та навичок соціальної взаємодії; активне оволодіння курсантами i слухачами способами та засобами особистісно-професійного самовдосконалення та соціальної взаємодії; формування у курсантів і слухачів навичок професійного спілкування й толерантності; підготовка науково-педагогічного складу до формування й розвитку соціальної компетентності у курсантів і слухачів.

Другий етап - перехідний - пов'язаний із циклом загальнопрофесійних, професійноорієнтованих дисциплін та практичної підготовки. Разом із попереднім циклом він забезпечує здобуття освітньо-кваліфікаційного рівня бакалавра. На перехідному етапі найважливішими педагогічними умовами визначено такі: конструювання змісту навчального матеріалу 3 урахуванням впливу на рефлексивно-психологічний i професійний компоненти соціальної компетентності; формування комунікативного та політико-правового компонентів соціальної компетентності на основі уміння курсантів використовувати варіативні способи розв'язання професійних завдань; підтримання сприятливого для формування соціальної компетентності соціальнопсихологічного середовища під час навчально-виховного процесу; забезпечення суб'єкт-суб'єктної взаємодії викладачів і курсантів як основи для наслідування соціально-доцільної поведінки під час виконання завдань професійної діяльності; застосування сучасних активних (проблемних, евристичних, інтерактивних) методів навчання як засобу активізації навчально-пізнавальної діяльності курсантів та опанування досвіду соціальної взаємодії; регулярна діагностика якості підготовки курсантів та сформованості усіх складників їх соціальної компетентності; педагогічна підтримка та супровід роботи курсантів з формування соціальної компетентності; відпрацювання навичок соціальної взаємодії під стажування на посадах за фахом підготовки.

Третій етап - завершальний - пов'язаний із здобуттям освітньо-кваліфікаційного рівня магістра. Технологія формування соціальної компетентності офіцера - магістра військового управління ОВС оперативно-тактичного рівня передбачає урахування специфіки виконання ним управлінських завдань, типових ситуацій його професійної діяльності, відповідно до чого визначено зміст, методи та прийоми навчальної роботи при організації навчального процесу на магістратурі. Характерними ознаками цієї технології $є$ спрямованість на забезпечення формування соціальної компетентності фахівців ОВС, відповідність основним положенням теорії навчання дорослих, а також принципам безперервності, поступовості, інтегративності, наступності, самоосвіти; взаємозв'язок дидактичного, психолого-педагогічного й методичного забезпечення із змістом професійної діяльності фахівців ОВС; комплексне використанням форм і методів роботи 3 формування соціальної компетентності; диференційований, індивідуально-орієнтований підхід до формування цієї професійно важливої властивості в офіцерів. Ці ознаки відповідають концепції та виділеним педагогічним умовам формування соціальної компетентності представників ОВС, найважливішими серед яких $є$ : планування тйа організація навчально-виховного процесу на засадах діяльнісного підходу, з використанням моделі офіцера-управлінця і орієнтуванням на кінцевий результат професійної підготовки; закріплення професійних умінь і навичок - складників соціальної компетентності; впровадження тренінгових методик для формування навичок соціальної взаємодії; стимулювання самостійної науководослідної роботи слухачів для поглиблення їх знань про сутність соціальної компетентності та соціальної взаємодії офіцера ОВС; формування та розвиток в офіцерів умінь і навичок командотворення, згуртування колективу підпорядкованих підрозділів, підтримання відповідного соціально-психологічного клімату в колективі; 
надання офіцерам знань 3 основ конфліктології для конструктивного розв'язання життєвих проблем і конфліктних ситуацій у професійно-управлінській діяльності та при охороні громадського порядку.

Технологія формування соціальної компетентності $є$ впорядкованою сукупністю психолого-педагогічних методів, прийомів, засобів, техніки виконання, спільної діяльності учасників педагогічного процесу для досягнення конкретною педагогічного результату - формування соціальної компетентності фахівців ОВС. Структура технології формування соціальної компетентності майбутніх офіцерів MBC містить змістовий i процесуальний компоненти. 3 урахуванням вікових соціально-психологічних особливостей курсантів і слухачів ВНЗ МВС, специфіки професійної підготовки і структури соціальної компетентності, для іiї формування у технології передбачено послідовне та поетапне впровадження педагогічних умов, які забезпечують досягнення мети попередніх етапів і відкривають шлях до подальшого pyxy.

Зазначена технологія найбільш повно відповідає вимогам формування соціальної компетентності, необхідності самореалізації особистості фахівців ОВС у спеціально організованій взаємодії та покликана підвищити ефективність їх підготовки до успішного функціонування в професійному та соціальному середовищі.

Перспективами подальших наукових розвідок $є$ експериментальна перевірка педагогічних умов і технології формування соціальної компетентності слухачів та курсантів вищих навчальних закладів МВС України.

\section{Література}

1. Беспалько В. П. Слагаемые педагогической технологии / В. П. Беспалько. М. : Педагогика, 1989. - 190 с. 2. Гузеев В. В. Педагогическая техника в контексте образовательной технологии / В. В. Гузеев. - М. : Народное образование, 2001.128 с. 3. Дичківська І. М. Інноваційні педагогічні технології : [навч. посіб.]/ I. М. Дичківська. - К. : Академвидав, 2004. - 352 с. 4. Кларин М. В. Инновации в обучении / М. В. Кларин. - М. : Наука, 1997. - 246 с. 5. Педагогика : учеб. пособ. [для студ. пед. вузов и педагогических колледжей]; под ред. П. И. Пидкасистого. - М. : Педагогика, 2006. - 608 с. 6. Селевко Г. К. Современные образовательные технологии : [учеб. пособ.] / Г. К. Селевко. - М. : Народное образование, 1998. - 256 с. 7. Сластенин В. А. Педагогика : [учеб. пособие для студ. высш. пед. учеб. заведений] / В. А. Сластенин, И. Ф. Исаев, Е. Н Шиянов; под ред. В. А. Сластенина. М. : Издательский центр «Академия», 2002. - 576 с. 8. Смирнов С. А. Педагогика : педагогические теории, системы, технологии : учеб. пособ. [для студ. высш. и сред. пед. учеб. заведений] / С. А. Смирнов, Е. Н. Шиянов; под ред. С. Л. Смирнова. - [4-е изд., испр.]. - М. : Издательский центр «Академия», 2001. - 512 с.

УДК 371.13.02:808.5

Людмила Топчій

\section{ПЕДАГОГІЧНІ УМОВИ ПІДГОТОВКИ МАЙБУТНІХ УЧИТЕЛІВ-ФІЛОЛОГІВ ДО ФОРМУВАННЯ СОЦІОКУЛЬТУРНОЇ КОМПЕТЕНТНОСТІ УЧНІВ СТАРШИХ КЛАСІВ ГІМНАЗЇ̈}

Топчій Л. С. Педагогічні умови підготовки майбутніх учителів-філологів до формування соціокультурної компетентності учнів старших класів гімназії.

У статті на основі аналізу соціальних перетворень i потреб сучасного суспільства, з одного боку, та вимог і очікувань щодо соціокультурної освіти у старшокласників-гімназистів, з іншого боку, визначено педагогічні умови підготовки 